\title{
Comparative Analysis of the Effects of Domestic Frying and Storage on Some Selected Oil Samples from Local and Commercial Sources
}

\author{
Gbadamosi Waheed Abiodun, Raji Ahmed Kolade and Oyegoke Jamal Adeyinka \\ Department of Chemistry, Federal University of Technology, PMB 704, Akure, Nigeria \\ e-mail: waheedabiodun013@gmail.com; rajiahmedkolade@gmail.com; oyegokejamal@yahoo.com
}

\begin{abstract}
Recent studies have shown that heating oil to high temperature causes oxidative degradation of the oil, consequently producing characteristics odour, taste, colour and texture. However, this study was conducted to evaluate the stability of four different samples of edible oils. Acid value was found to be 5.22, 3.50, 0.73 and $1.29 \mathrm{mg} \mathrm{KOH} / \mathrm{g}$ oil in fresh Melon, Bushmango, olive and Palm olein oils samples respectively. When the four oil samples were used for frying, the acid value was found to be; 6.73, 3.90, 2.24 and $2.24 \mathrm{mg} \mathrm{KOH} / \mathrm{g}$ oil (24 hours after frying), 11.22, 7.86, 4.49 and $3.3 \mathrm{mg} \mathrm{KOH} / \mathrm{g}$ oil (2 weeks after frying) and 19.17, 13.22, 5.82 and $4.4 \mathrm{mg} \mathrm{KOH} / \mathrm{g}$ oil (4 weeks after frying), for melon, Bushmango, olive and palm olein oils samples respectively. Saponification values were ranged between 196.70-240.00 mg KOH/g oil in fresh oils of the samples, and between $197.80-252.33 \mathrm{mg} \mathrm{KOH} / \mathrm{g}$ oil in the oils after using them for frying. Furthermore, Peroxide values ranged from 2.65 to $3.20 \mathrm{Meq} / \mathrm{Kg}$ in fresh oils of the samples, and from 2.71 to $24.00 \mathrm{Meq} / \mathrm{Kg}$ in frying oils were to exceed the permitted value of $20 \mathrm{meq} / \mathrm{Kg}$ for olive oil and $10 \mathrm{meq} / \mathrm{Kg}$ for other edible oils in nearly half the analyzed samples. In general, feeding on these kinds of edible oils which have high values of acidity and peroxides is very dangerous because of the destructive effects of peroxide compounds and acidity on the components of the membranes of the living cell.
\end{abstract}

\section{Introduction}

Edible oil is one of the chosen ingredients of diets that is used for cooking purposes. Received: September 30, 2019; Accepted: November 16, 2019

Keywords and phrases: acid value, saponification value, peroxide value, melon oil, Bushmango oil, olive oil, palm olein oil.

Copyright (C) 2020 Raji Ahmed Kolade et al. This is an open access article distributed under the Creative Commons Attribution License, which permits unrestricted use, distribution, and reproduction in any medium, provided the original work is properly cited. 
It is a vital module of food; it provides energy, essential fatty acid and serves as a carrier of fat-soluble vitamins $(\mathrm{g})$. The most common application of edible oils is in deep-frying, salad dressings and food emulsions [1]. Deep-fat frying is the cooking of food in preheated deep oil/fat at a high temperature of 150 to $190^{\circ} \mathrm{C}$ [4]. Fried foods have desirable flavor, color, and crispy texture, which make deep-fat fried foods very popular to consumers [10]. During the frying process, oil undergoes changes in physical, chemical, nutritional and sensory properties, which affects its frying performance [4]. The repeated use of oil could affect the shelf-life and nutritional quality of fried foods due to the development of rancidity in the frying oil taken up by the products [7, 8]. The quality of any oil is indicated by some physicochemical properties. The specific value of some of these properties provides an indication of both the nutritive and physical quality of the oil. These properties include iodine value, peroxide value, saponification value, unsaponifiable value, free fatty acid, color appearance etc. Research studies have indicated that vegetable cooking oils are used 3-6 times before being discarded as waste [5]. Repetitive use of vegetable oil lowers the smoke point, which is the temperature at which the oil breaks down creating acrolein, an obnoxious smelling compound; and visible fumes are given off [6]. Vegetable oil quality is largely dependent on its resistance to oxidation. Chemical stability, which might ultimately be regarded as resistance to oxidation, depends on the chemical composition of the oil, especially antioxidants and oxidizable compounds, and on physical interfaces and microenvironments in which the reactants interact. (e) Physicochemical properties like Specific gravity, moisture content, viscosity, Acid value, free fatty acid, and peroxide value, saponification and iodine values of fresh Melon, Bushmango, olive and Palm olein oils samples were studied to evaluate the compositional quality of these oils and also to investigate the effect on the use of same oils for repeated frying on long term storage as it greatly changes the physicochemical, nutritional and sensory properties of these oils.

\section{Materials and Methods}

\section{Sample collection and preparation}

Four oil samples were used for this study, of which two of the oil samples precisely Power vegetable oil (Palm Olein) and Goya olive oil (Olive Oil) were bought from OjaOba market in Akure and two oils seeds; melon seed (Cucumis melo) and Bush-mango seed (Irvingia gabonensis) were also bought from the same market. The seeds were sorted to remove debris and sun dried until constant mass was obtained. Prior to this, the 
seed coat of the melon was removed by dehulling. They were ground into powder using Binatone mixer/grinding machine, packed in air tight containers and kept in the refrigerator at $4^{\circ} \mathrm{C}$ for further processing.

\section{Extraction of oil from the seed}

About $300 \mathrm{ml}$ of $\mathrm{n}$-hexane was poured into the round bottom flask of the extractor. Five hundred grams of each sample seed was wrapped in a white muslin cloth and placed in the thimble of the soxhlet extractor. The oils samples were extracted from the seed flours by soxhlet extraction using n-hexane of Analar grade, boiling range $40^{\circ} \mathrm{C}-60^{\circ} \mathrm{C}$. The soxhlet was coupled with condenser and flask already filled with n-hexane. The set up was heated on heat mantle at $65^{\circ} \mathrm{C}$ to allow solvent boiling, in the process the solvent vapour travels up a distillation arm and flowed into the chamber housing the sample material. The extract seeps through the pores of the thimble and fills the siphon tube where it flows back down into the round bottom flask. The process was allowed to continue for 3 hours until a clear solvent was obtained in the thimble chamber. At the end of the extraction, the resulting mixture containing the oil was heated to recover the solvent from the oil. The recovered oil was stored at room temperature prior to analysis.

\section{Frying process}

The oil samples $(250 \mathrm{ml})$ was poured into a frying pan and $150 \mathrm{~g}$ of each of plantain and yam was introduced was fried one after the other. The pan was placed on heat mantle set at $160-180^{\circ} \mathrm{C}$ and allowed to fry for 10 minutes. The process was repeated for all the oils samples at the same frying conditions.

\section{Oils storage}

The oil samples were stored at room temperature before use and after use for four weeks in which the analysis of the physicochemical properties are being carried out at intervals at 24 hours, 2 weeks and 4 weeks of storage.

\section{Determination of the physicochemical properties of the oils}

The analytical estimations were made for water (moisture) content, colour, taste, odour, viscosity, specific density, refractive index, acid value, saponification value, iodine value, perioxide value, and free fatty acid.

\section{Moisture content determination}

An empty evaporating dish was washed and dried in the oven and allowed to cool in 
the desiccator and then weighed $\left(\mathrm{W}_{1}\right)$. About $2.0 \mathrm{~g}$ of the oil sample was weighed into the dish and weighed $\left(\mathrm{W}_{2}\right)$. The dish containing the sample was oven dried maintaining the temperature at $105^{\circ} \mathrm{C}$ for three (3) hours until a constant weight was obtained after cooling in the desiccator. The constant weight after cooling was recorded $\left(\mathrm{W}_{3}\right)$. The loss in the weight after drying was recorded in percentage.

$$
\begin{aligned}
\% \text { Moisture } & =\frac{\text { weight loss }}{\text { weight of sample }} \times 100 \\
& =\frac{\mathrm{W}_{2}-\mathrm{W}_{3}}{\mathrm{~W}_{2}-\mathrm{W}_{1}} \times 100
\end{aligned}
$$

where, $\mathrm{W}_{1}=$ Weight of empty crucible $(\mathrm{g})$

$\mathrm{W}_{2}=$ Weight of crucible + sample before drying $(\mathrm{g})$

$\mathrm{W}_{3}=$ Weight of crucible + sample after drying $(\mathrm{g})$.

\section{Determination of specific gravity}

This is the ratio of the weight of the oil sample in grams to that of equal volume of water in grams. A density bottle with its stopper was weighed $\left(\mathrm{W}_{1}\right)$, filled with the oil, covered with its stopper and re-weighed $\left(\mathrm{W}_{2}\right)$. The density bottle was washed, drained, filled with water and weighed $\left(\mathrm{W}_{3}\right)$.

$$
\text { Specific gravity }=\frac{\mathrm{W}_{2}-\mathrm{W}_{1}}{\mathrm{~W}_{3}-\mathrm{W}_{1}},
$$

where, $\mathrm{W}_{1}$ = weight of density bottle with its stopper $(\mathrm{g})$

$\mathrm{W}_{2}=$ weight of density bottle with its stopper + oil $(\mathrm{g})$

$\mathrm{W}_{3}$ = weight of density bottle with its stopper + water $(\mathrm{g})$.

\section{Determination of colour}

The oil sample was poured into a clear, transparent glass tube and viewed under white light. The colour was assigned to it by visual inspection.

\section{Determination of refractive index}

In the determination of the refractive index of the oil samples, Abbe 60 refractometer 
was used. Two drops of the oil sample were placed in the glass prism sample compartment. The instrument was allowed to stand for 10 minutes in order to attain a steady temperature after which the reading of the refractive index was recorded [11].

\section{Determination of acid value and free fatty value}

About $1 \mathrm{~g}$ of the sample was weighed into a conical flask; $25 \mathrm{ml}$ of $95 \%$ alcohol was added followed by the stepwise addition of 2 drops of phenolphthalein indicator. The solution was titrated with standardized $0.1 \mathrm{M}$ potassium hydroxide until a faint colour appears [9].

$$
\text { Acid value }=\frac{\text { Titre Value } \times 5.61}{\text { Weight of Sample }}
$$

The acid value is measured in $\mathrm{mgKOH} / \mathrm{g}$.

The FFA can be determined from the same titration as in acid value using the expression below. It is expressed as oleic acid (octadec-9-enoic acid) equivalent (mg/g)

$$
\% \text { free fatty acid }=\frac{\text { Titre Value } \times 2.82}{\text { Weight of Sample }} .
$$

\section{Iodine value determination}

About $0.5 \mathrm{~g}$ of the oil sample was weight into a glass-stopper bottle of about $250 \mathrm{ml}$ capacity. $10 \mathrm{ml}$ carbon tetrachloride $\left(\mathrm{CCl}_{4}\right)$ was added with a dry measuring cylinder and the flask was shaken to dissolve the oil. An aliquot $20 \mathrm{ml}$ of Wij's solution was pipetted into the flask and the stopper being moistened with $10 \%$ potassium iodide solution (KIaq) was inserted. The whole solution was allowed to stand in the dark for thirty minutes. $15 \mathrm{ml}$ of $10 \%(\mathrm{~V} / \mathrm{V})$ potassium iodide solution and $100 \mathrm{ml}$ distilled water was added. The iodine liberated was 37 back titrated with $25 \mathrm{ml} 0.1 \mathrm{ml}$ standard sodium thiosulphate $\left(\mathrm{Na}_{2} \mathrm{~S}_{2} \mathrm{O}_{3}(\mathrm{aq})\right)$. The equation of reaction is shown below:

$$
2 \mathrm{~S}_{2} \mathrm{O}_{3(\mathrm{aq})}+2 \mathrm{I} \longrightarrow \mathrm{S}_{4} \mathrm{O}^{2-}+2 \mathrm{I}^{-}{ }_{(\mathrm{aq})}
$$

This is done until the titrant has a straw colour and at this point, the starch indicator is added drop-wisely and the titration continues to a colourless end point. This procedure is repeated for the blank [9]. 


$$
\text { Iodine Value }=\frac{(\mathrm{b}-\mathrm{a}) \times \mathrm{M} \times 12.69}{\text { Weight of Sample }}
$$

where, $\mathrm{M}=$ Molarity of thiosulphate used

$\mathrm{a}=$ sample titre value

$\mathrm{b}=$ Blank titre value.

\section{Determination of saponification value}

About $1 \mathrm{~g}$ of the oil sample was weighed into $250 \mathrm{ml}$ conical flask followed by the addition of $25 \mathrm{ml}$ of potassium hydroxide solution, then refluxed for 30 minutes with occasional shaking. $1 \mathrm{ml}$ of phenolphthalein indicator was added to the solution and titrated while hot with $0.5 \mathrm{M} \mathrm{HCl}$ solution (a ml). A blank titration was carried out which contained all the reagents without the sample ( $\mathrm{b} \mathrm{ml}$ ). The colour changed from pink to colourless [9].

Calculation:

$$
\text { Saponification Value }=\frac{(\mathrm{b}-\mathrm{a}) \mathrm{ml} \times 28.05}{\text { Weight of Sample }},
$$

where, $b=$ Titre value of blank

$$
\mathrm{a}=\text { Titre value of the sample. }
$$

\section{Determination of peroxide value}

This test was carried out in the dark. About $1 \mathrm{~g}$ of the oil sample was weighed into a clean conical flask and placed on boiling water bath for 1 minute. $1 \mathrm{~g}$ powdered potassium iodide and $20 \mathrm{ml}$ of the solvent mixture of acetic and chloroform (3:1) was added. The content was poured into a titration flask which contained $20 \mathrm{ml}$ potassium iodide solution and the tube was washed with $25 \mathrm{ml}$ portion of water and added to the titration flask which was then titrated against $0.002 \mathrm{M}$ Sodium thiosulphate using starch as indicator [9].

Calculation:

$$
\text { Peroxide Value }=\frac{0.002 \mathrm{M} \times(\text { Sample titre }- \text { Blank titre }) \times 1000}{\text { Weight of Sample }} .
$$

\section{Statistical analysis}

The results of the physicochemical properties of the oils were expressed as means \pm 
standard deviation (SD) of three replicates. Data obtained were statistically analyzed using one-way Analysis of Variance (ANOVA), a tool in statistical packages for social sciences (SPSS 16.0). The level of significance was set at $\mathrm{p}<0.05$. Means were separated with Turkey Multiple Range Test (TMRT).

\section{Results and Discussion}

Some chemical and physical characteristics of Melon oil, Bushmango oil, Olive oil and Palm olein oils before and after frying have been extensively investigated. The data of specific gravity values, moisture contents values, viscosity values, saponification value, peroxides values, acid values, free fatty acids value and iodine values of Melon oil, Bushmango oil, Olive oil and Palm olein oil are illustrated in below tables.

Table 1. Viscosity values (cP) of vegetable oil samples before and after frying.

\begin{tabular}{|c|c|c|c|c|}
\hline & Before frying & 24 hours after & 2 weeks after & 4 weeks after $^{\text {Melon Oil }}$ \\
\hline $19.06 \pm 0.04^{\mathrm{d}}$ & $29.15 \pm 0.04^{\mathrm{c}}$ & $45.08 \pm 0.03^{\mathrm{b}}$ & $48.23 \pm 0.20^{\mathrm{a}}$ \\
\hline Bushmango Oil & $46.14 \pm 0.02^{\mathrm{d}}$ & $55.26 \pm 0.03^{\mathrm{c}}$ & $86.50 \pm 0.03^{\mathrm{b}}$ & $88.48 \pm 0.04^{\mathrm{a}}$ \\
\hline Olive Oil & $27.05 \pm 0.04^{\mathrm{d}}$ & $44.60 \pm 0.04^{\mathrm{c}}$ & $70.02 \pm 0.02^{\mathrm{b}}$ & $74.37 \pm 0.01^{\mathrm{a}}$ \\
\hline Palm Olein & $40.06 \pm 0.02^{\mathrm{d}}$ & $56.66 \pm 0.05^{\mathrm{c}}$ & $80.09 \pm 0.01^{\mathrm{b}}$ & $82.23 \pm 0.02^{\mathrm{a}}$ \\
\hline
\end{tabular}

Values are mean \pm standard deviation of triplicate determinations. Values with the same superscript within the rows are not significantly different at $\mathrm{p}<0.05$.

Table 2. Specific gravity values of vegetable oil samples before and after frying.

\begin{tabular}{|c|c|c|c|c|}
\hline & Before frying & 24 hours after & 2 weeks after & 4 weeks after Melon Oil \\
$0.91 \pm 0.01^{\mathrm{b}}$ & $0.92 \pm 0.01^{\mathrm{a}}$ & $0.92 \pm 0.02^{\mathrm{a}}$ & $0.92 \pm 0.006^{\mathrm{a}}$ \\
\hline Bushmango Oil & $0.80 \pm 0.01^{\mathrm{b}}$ & $0.91 \pm 0.02^{\mathrm{a}}$ & $0.91 \pm 0.00^{\mathrm{a}}$ & $0.91 \pm 0.00^{\mathrm{a}}$ \\
\hline Olive Oil & $0.91 \pm 0.01^{\mathrm{a}}$ & $0.91 \pm 0.01^{\mathrm{a}}$ & $0.91 \pm 0.02^{\mathrm{a}}$ & $0.91 \pm 0.01^{\mathrm{a}}$ \\
\hline Palm Olein & $0.91 \pm 0.01^{\mathrm{a}}$ & $0.92 \pm 0.01^{\mathrm{a}}$ & $0.92 \pm 0.02^{\mathrm{a}}$ & $0.92 \pm 0.006^{\mathrm{a}}$ \\
\hline
\end{tabular}

Values are mean \pm standard deviation of triplicate determinations. Values with the same superscript within the rows are not significantly different at $\mathrm{p}<0.05$. 
Table 3. Moisture content values of vegetable oil samples before and after frying.

\begin{tabular}{|c|c|c|c|c|}
\hline & Before frying & 24 hours after & 2 weeks after & 4 weeks after \\
\hline Melon Oil & $2.00 \pm 0.20^{\mathrm{a}}$ & $1.00 \pm 0.02^{\mathrm{b}}$ & $1.00 \pm 0.00^{\mathrm{b}}$ & $0.84 \pm 0.006^{\mathrm{c}}$ \\
\hline Bushmango Oil & $3.00 \pm 0.01^{\mathrm{a}}$ & $1.50 \pm 0.01^{\mathrm{b}}$ & $1.30 \pm 0.10^{\mathrm{c}}$ & $0.92 \pm 0.01^{\mathrm{d}}$ \\
\hline Olive Oil & $2.00 \pm 0.02^{\mathrm{a}}$ & $0.50 \pm 0.02^{\mathrm{a}}$ & $0.67 \pm 0.01^{\mathrm{c}}$ & $0.50 \pm 0.02^{\mathrm{b}}$ \\
\hline Palm Olein & $2.00 \pm 0.02^{\mathrm{a}}$ & $1.00 \pm 0.02^{\mathrm{b}}$ & $0.67 \pm 0.006^{\mathrm{c}}$ & $0.49 \pm 0.006^{\mathrm{d}}$ \\
\hline
\end{tabular}

Values are mean \pm standard deviation of triplicate determinations. Values with the same superscript within the rows are not significantly different at $\mathrm{p}<0.05$.

Table 4. Percentage change in acid values $(\mathrm{MgKOH} / \mathrm{g})$ of vegetable oils after frying.

\begin{tabular}{|c|c|c|c|c|c|c|c|}
\hline & & & & & Percen & age change aft & frying \\
\hline & Before frying & 24 hours after & 2 weeks after & 4 weeks after & 24 hours after & 2 weeks after & 4 weeks after \\
\hline Melon Oil & $5.22^{\mathrm{d}} \pm 0.03$ & $6.73^{\mathrm{c}} \pm 0.05$ & $11.22^{\mathrm{b}} \pm 0.2$ & $9.59^{\mathrm{a}} \pm 0.01$ & $29.93^{\mathrm{c}} \pm 1.47$ & $115.02^{\mathrm{b}} \pm 1.21$ & $267.31^{\mathrm{a}} \pm 1.24$ \\
\hline Bushmango Oil & $3.50^{\mathrm{d}} \pm 0.02$ & $3.90^{\mathrm{c}} \pm 0.02$ & $7.86^{\mathrm{b}} \pm 0.03$ & $13.22^{\mathrm{a}} \pm 0.01$ & $11.24^{\mathrm{c}} \pm 0.72$ & $125.19^{\mathrm{b}} \pm 1.59$ & $277.72^{\mathrm{a}} \pm 2.02$ \\
\hline Olive Oil & $1.26^{\mathrm{d}} \pm 0.01$ & $2.20^{\mathrm{c}} \pm 0.03$ & $3.01^{\mathrm{b}} \pm 0.01$ & $4.04^{\mathrm{a}} \pm 0.02$ & $74.60^{c} \pm 0.93$ & $138.89^{\mathrm{b}} \pm 3.21$ & $220.65^{\mathrm{a}} \pm 1.87$ \\
\hline Palm Olein & $1.29^{\mathrm{d}} \pm 0.01$ & $2.24^{\mathrm{c}} \pm 0.01$ & $3.37^{\mathrm{b}} \pm 0.02$ & $4.49^{\mathrm{a}} \pm 0.01$ & $75.65^{\mathrm{c}} \pm 0.97$ & $161.25^{\mathrm{b}} \pm 3.10$ & $248.27^{\mathrm{a}} \pm 1.93$ \\
\hline
\end{tabular}

Values are mean \pm standard deviation of triplicate determinations. Values with the same superscript within the rows are not significantly different at $\mathrm{p}<0.05$.

Table 5. Percentage change of free fatty acid values $(\mathrm{MgKOH} / \mathrm{g})$ of vegetable oils after frying.

\begin{tabular}{|c|c|c|c|c|c|c|c|}
\hline & \multirow[b]{2}{*}{ Before frying } & \multirow[b]{2}{*}{24 hours after } & \multirow[b]{2}{*}{2 weeks after } & \multirow[b]{2}{*}{4 weeks after } & \multicolumn{3}{|c|}{ Percentage change after frying } \\
\hline & & & & & 24 hours after & 2 weeks after & 4 weeks after \\
\hline Melon Oil & $2.61^{\mathrm{d}} \pm 0.02$ & $3.37^{\mathrm{c}} \pm 0.03$ & $5.61^{\mathrm{b}} \pm 0.01$ & $9.59^{\mathrm{a}} \pm 0.01$ & $28.67^{\mathrm{c}} \pm 1.58$ & $115.08^{\mathrm{b}} \pm 1.70$ & $267.32^{\mathrm{a}} \pm 3.0$ \\
\hline Bushmango Oil & $1.75^{\mathrm{d}} \pm 0.01$ & $1.95^{\mathrm{c}} \pm 0.01$ & $3.94^{\mathrm{b}} \pm 0.02$ & $6.61^{\mathrm{a}} \pm 0.01$ & $11.43^{\mathrm{c}} \pm 1.04$ & $125.19^{\mathrm{b}} \pm 1.59$ & $277.91^{\mathrm{a}} \pm 1.88$ \\
\hline Olive Oil & $0.63^{\mathrm{d}} \pm 0.01$ & $1.10^{\mathrm{c}} \pm 0.02$ & $1.15^{\mathrm{b}} \pm 0.01$ & $2.02^{\mathrm{a}} \pm 0.01$ & $74.60^{\mathrm{c}} \pm 2.18$ & $139.68^{\mathrm{b}} \pm 3.54$ & $220.63^{\mathrm{a}} \pm 2.05$ \\
\hline Palm Olein & $0.65^{\mathrm{d}} \pm 0.01$ & $1.12^{\mathrm{c}} \pm 0.01$ & $1.69^{\mathrm{b}} \pm 0.01$ & $2.25^{\mathrm{a}} \pm 0.01$ & $72.33^{\mathrm{c}} \pm 2.29$ & $159.54^{\mathrm{b}} \pm 4.77$ & $248.72^{\mathrm{a}} \pm 2.22$ \\
\hline
\end{tabular}

Values are mean \pm standard deviation of triplicate determinations. Values with the same superscript within the rows are not significantly different at $\mathrm{p}<0.05$. 
Table 6. Percentage change of peroxide value of vegetable oils after frying.

\begin{tabular}{|c|c|c|c|c|c|c|c|}
\hline \multicolumn{4}{|c|}{} & \multicolumn{4}{c|}{ Percentage change after frying } \\
\hline & Before frying & $\mathbf{2 4}$ hours after & $\mathbf{2}$ weeks after & 4 weeks after & $\mathbf{2 4}$ hours after & 2 weeks after & 4 weeks after \\
\hline Melon Oil & $2.65^{\mathrm{c}} \pm 0.05$ & $2.71^{\mathrm{c}} \pm 0.02$ & $7.21^{\mathrm{b}} \pm 0.02$ & $12.03^{\mathrm{a}} \pm 0.01$ & $73.21^{\mathrm{c}} \pm 2.19$ & 172.0 & $354.20^{\mathrm{a}} \pm 8.57$ \\
\hline Bushmango Oil & $2.75^{\mathrm{c}} \pm 0.01$ & $2.80^{\mathrm{c}} \pm 0.04$ & $5.60^{\mathrm{b}} \pm 0.02$ & $24.0^{\mathrm{a}} \pm 0.0$ & $1.82^{\mathrm{c}} \pm 1.68$ & 103.5 & $727.73^{\mathrm{a}} \pm 3.17$ \\
\hline Olive Oil & $3.20^{\mathrm{c}} \pm 0.01$ & $3.20^{\mathrm{c}} \pm 0.05$ & $3.59^{\mathrm{b}} \pm 0.09$ & $9.20^{\mathrm{a}} \pm 0.02$ & $1.26^{\mathrm{c} \pm 0.84}$ & 12.39 & $187.50^{\mathrm{a}} \pm 0.79$ \\
\hline Palm Olein & $3.10^{\mathrm{c}} \pm 0.04$ & $3.12^{\mathrm{c}} \pm 0.03$ & $3.72^{\mathrm{b}} \pm 0.02$ & $8.60^{\mathrm{a}} \pm 0.01$ & $0.65^{\mathrm{c}} \pm 0.33$ & 20.01 & $177.56^{\mathrm{a}} \pm 3.58$ \\
\hline
\end{tabular}

Values are mean \pm standard deviation of triplicate determinations. Mean values followed by the same superscript within the rows are not significantly different at $\mathrm{p}<0.05$.

Table 7. Iodine values of vegetable oil samples before and after frying.

\begin{tabular}{|c|c|c|c|c|}
\hline & Before frying & 24 hours after & 2 weeks after & 4 weeks after \\
\hline Melon Oil & $110.02 \pm 0.02^{\mathrm{a}}$ & $104.70 \pm 0.08^{\mathrm{b}}$ & $92.83 \pm 0.03^{\mathrm{c}}$ & $70.91 \pm 0.01^{\mathrm{d}}$ \\
\hline Bushmango Oil & $13.40 \pm 0.03^{\mathrm{a}}$ & $10.30 \pm 0.03^{\mathrm{b}}$ & $6.57 \pm 0.01^{\mathrm{c}}$ & $3.01 \pm 0.01^{\mathrm{d}}$ \\
\hline Olive Oil & $81.20 \pm 0.06^{\mathrm{a}}$ & $77.40 \pm 0.01^{\mathrm{b}}$ & $65.99 \pm 0.01^{\mathrm{c}}$ & $53.98 \pm 0.01^{\mathrm{d}}$ \\
\hline Palm Olein & $54.10 \pm 0.02^{\mathrm{a}}$ & $52.00 \pm 0.02^{\mathrm{b}}$ & $44.54 \pm 0.01^{\mathrm{c}}$ & $32.61 \pm 0.01^{\mathrm{d}}$ \\
\hline
\end{tabular}

Values are mean \pm standard deviation of triplicate determinations. Mean values followed by the same superscript within the rows are not significantly different at $\mathrm{p}<0.05$.

Table 8. Saponification values of vegetable oil samples before and after frying.

\begin{tabular}{|c|c|c|c|c|}
\hline & Before frying & 24 hours after & 2 weeks after & 4 weeks after \\
\hline Melon Oil & $196.70 \pm 0.05^{\mathrm{c}}$ & $197.80 \pm 0.06^{\mathrm{c}}$ & $200.03 \pm 0.10^{\mathrm{b}}$ & $211.40 \pm 0.02^{\mathrm{a}}$ \\
\hline Bushmango Oil & $240.00 \pm 0.08^{\mathrm{d}}$ & $242.01 \pm 0.05^{\mathrm{c}}$ & $246.27 \pm 0.15^{\mathrm{b}}$ & $252.33 \pm 0.006^{\mathrm{a}}$ \\
\hline Olive Oil & $190.00 \pm 0.80^{\mathrm{d}}$ & $191.53 \pm 0.02^{\mathrm{c}}$ & $193.67 \pm 0.02^{\mathrm{b}}$ & $199.63 \pm 0.01^{\mathrm{a}}$ \\
\hline Palm Olein & $196.00 \pm 0.30^{\mathrm{d}}$ & $198.40 \pm 0.04^{\mathrm{c}}$ & $201.01 \pm 0.01^{\mathrm{b}}$ & $206.41 \pm 0.01^{\mathrm{a}}$ \\
\hline
\end{tabular}

Values are mean \pm standard deviation of triplicate determinations. Mean values followed by the same superscript within the rows are not significantly different at $\mathrm{p}<0.05$. 


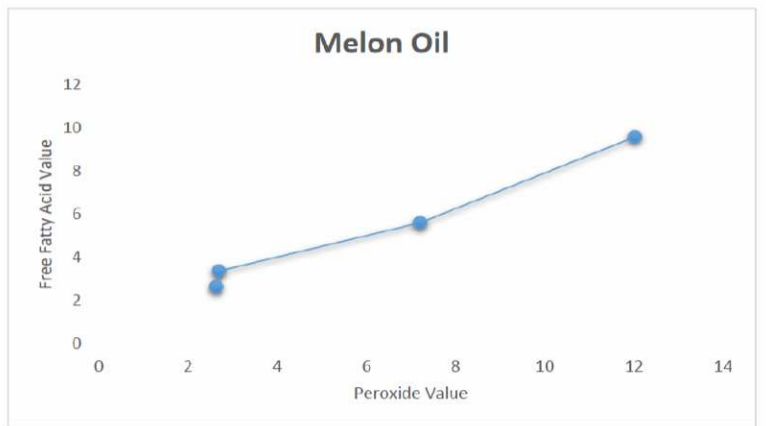

Figure 1. Graph of free fatty acid versus peroxide value for melon oil. Correlation Coefficient is 0.991445 .

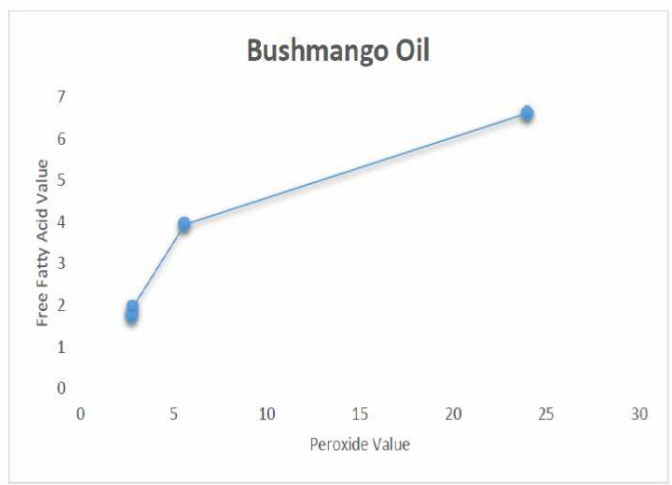

Figure 2. Graph of free fatty acid versus peroxide for Bushmango oil.

Correlation coefficient is 0.948383 .

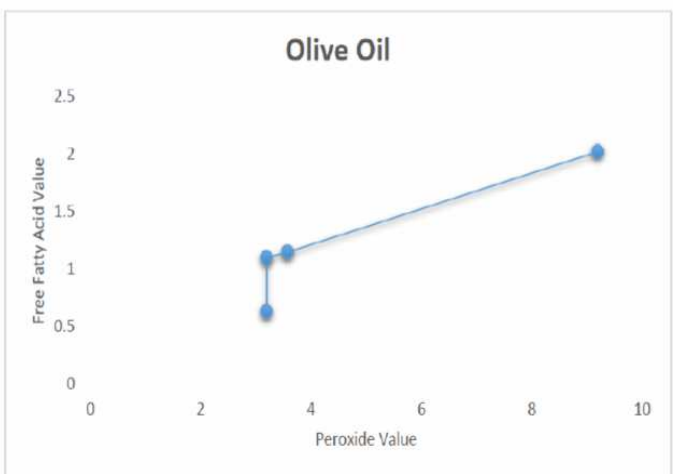

Figure 3. Graph of free fatty acid versus peroxide value for olive oil.

Correlation coefficient is 0.92736 . 


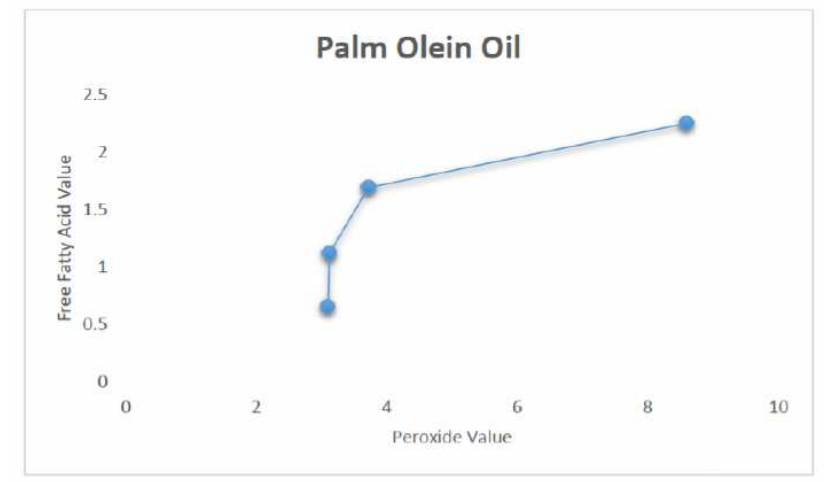

Figure 4. Graph of free fatty acid value versus peroxide value.

Correlation coefficient is 0.845579 .

\section{Discussions}

Figures 1 to 4 show the relationship between the free fatty and peroxide values obtained during the analysis of the oil samples. The graphs of free fatty acid against peroxide values showed that the peroxide values increased with increasing free fatty acid content $(2.61,2.65)$ of the oil samples. From Figure 1, the peroxide value for Melon oil increased slightly with increase in free fatty acid value at the initial stage but increased almost at the same rate $(9.59,12.03)$ as the free fatty acid with storage time. Also from Figure 2, the peroxide value of Bushmango oil increased slightly with increasing free fatty acid $(1.75,2.75)$ contents of the oil but increase progressively with slight increase in free fatty acid values $(6.61,24.0)$. This indicated that peroxidation takes place more in Bushmango oil than in Melon oil. It can also be observed from Table 8 that the peroxide value of the olive oil increased with free fatty acid at fresh $(0.63,3.20)$ and became stable at 24 hours after frying. The value of the peroxide then increased greatly with slight increase in free fatty acid content of the oil at 4 weeks after frying $(2.02,9.20)$. The increase observed in the peroxide value of the palm olein oil with increasing free fatty acid content is similar to that which was observed for olive oil as shown in Figure 4. Generally, Figures 1 to 4 show a great increase in the values of the peroxide values with slight increase in the free fatty acid contents of the oils. The rate of increment in the peroxidation observed in the commercial samples is a bit minimal compared to their counterpart local samples, which may be due to a certain antioxidant that might have been added during their manufacturing processes to lower the rate of peroxide formation. 


\section{Viscosity}

Oils are mixture of triglycerides (TGS) and their viscosity depends on the nature of the triglycerides present in the oil. The viscosity changed due to the different arrangement of the fatty acids on the glycerol backbone of the triglyceride molecule. Therefore, the viscosity is related to the chemical properties of the oils such as chain length and saturation or unsaturation. Table 1 shows that at room temperature $\left(27^{\circ} \mathrm{C}\right)$ the viscosity of the oils increase with storage time and highest in Bushmango oil (88.43 cP) than others, while melon oil $(48.23 \mathrm{cP})$ has the least viscosity at 4 weeks of storage after use. The viscosity obtained for fresh oils (before frying) were however lower than the values recorded for crude (68.04) and refined (56.28) canarium fruit oil by [12]. The viscosity values were however higher at 4 weeks after frying with the oil samples. The results indicated that the viscosity increases with storage time. Viscosity also depends on sheer stress and temperature. Sheer stress does not have much effect on the storage of oils which are used for edible purpose but the temperature does affect it. On a general note Table 4 shows that the viscosity of the oil increases at different frying times with yam and plantain. When the temperature increases, the kinetic energy (KE) also increases which enhances movement of the molecules and reduces the outer molecular forces. The layers of the liquid easily pass over one another and this contributes to the reduction of viscosity. There was significant difference $(\mathrm{p}<0.05)$ in the values obtained for the oils at the different time of analysis.

\section{Specific Gravity (SPGR)}

The specific gravity of the oils is as shown in Table 2. It shows that there was no significance $(\mathrm{p}<0.05)$ difference in the values obtained for all the oils as against the values, recorded by [16] for mustard oil and corn oil which increases with increasing temperature as well as using the oil for frying three times. However, from the Table 2 it shows that the specific gravity of the oils ranges from $0.80 \mathrm{~g} / \mathrm{ml}$ to $0.92 \mathrm{~g} / \mathrm{ml}$ with Bushmango having the least before frying (fresh oil) and melon oil and palm olein having $0.92 \mathrm{~g} / \mathrm{ml}$ respectively at four weeks after frying. The specific gravities of the oil were related to the standard range of $0.898 \mathrm{~g} / \mathrm{ml}-0.907 \mathrm{~g} / \mathrm{ml}$ approved by the standard organization of Nigeria [17]. The high values of the specific gravities as compared with the standard may however be due to the pie $(\pi)$ bonds that make the bonding more rigid and rotation between $\mathrm{C}-\mathrm{C}$ becomes more strenuous. The oxidation products that develop in triacylglycerol are hydroperoxides which May later break down to produce lower 
molecular weight compounds such as free fatty acids, alcohol, aldehydes, eventually to a rancid product.

\section{Peroxide Value}

The peroxide value was also found to increase with storage time, temperature and contact with air by the oil samples. Therefore, high peroxide value is an indication of high oxidative rancidity. The peroxide values obtained in this study increases from 2.65 to $24.0 \mathrm{meq} / \mathrm{Kg}$ from fresh state to 4 weeks after storage. However, lower values were obtained for the commercial oil samples of $9.20 \mathrm{meq} / \mathrm{Kg}$ and $8.60 \mathrm{meq} / \mathrm{Kg}$ for Olive oil and Palm olein respectively as against the high values of 12.03 and 24.0 for Melon and Bushmango respectively at four weeks after frying. This indicates that some refining process of the commercial oils has significantly $(\mathrm{p}<0.05)$ reduced the peroxide value. However, the peroxide values obtained for the oil samples at fresh (before frying), 24 Hrs., and 2 weeks after frying were below the maximum acceptable limit of $10 \mathrm{meq} / \mathrm{Kg}$ set by the Codex Alimentarius Commission for edible oils [20]. Low peroxide value of the oils samples indicates high resistance to peroxidation and low rate of spoilage. From Table 6, it can be observed that all the four oil samples had small values of peroxide which ranges from $2.65 \mathrm{meq} / \mathrm{kg}$ to $3.20 \mathrm{meq} / \mathrm{kg}$ with highest value $(3.20 \mathrm{meq} / \mathrm{kg})$ recorded for olive oil. Meanwhile after frying, these oils showed a moderately high peroxide values which ranges from $2.71 \mathrm{meq} / \mathrm{kg}$ to $24.0 \mathrm{meq} / \mathrm{kg}$ in which the highest value $(24.0 \mathrm{meq} / \mathrm{kg})$ was recorded for Bushmango oil at 4 weeks after frying. Also from Table 6 , it can be observed that the percentage change in the peroxide value increased from $0.65 \%$ at 24 hours after frying to $727.73 \%$ at 4 weeks after frying with the highest percentage change (727.73\%) recorded for Busmango oil which increases from $1.82 \%$ at 24 hours after frying to $727.73 \%$ at 4 weeks after frying. Thus, it can be concluded that peroxidation increases at room temperature with increasing storage time. Based on the results, the oil samples can be classified into moderate oxidation and high oxidation state based on the results calculated for the peroxide values. A product with peroxide values between 5 and $10 \mathrm{meq} / \mathrm{kg}$ is at moderate oxidation state above $10 \mathrm{meq} / \mathrm{kg}$ is at high oxidation state [2]. Also from the table it could be observed that the rate of peroxidation in the local oils are more compare to the commercial oils with Bushmango oil having a peroxide value of $24.00 \mathrm{meq} / \mathrm{kg}$ at 4 weeks after frying, so also is melon oil with 12.03 $\mathrm{meq} / \mathrm{kg}$ in contrast to olive oil with palm oil olein with 9.20 and $8.60 \mathrm{meq} / \mathrm{kg}$ respectively at the same period. This could be as a result of certain antioxidant (such as 
vitamin $\mathrm{E}$ or $\mathrm{C}$ ) that might have been added to the commercial oil during processing to lower the rate of peroxidation and development of rancidity. While the high values noticed in the local oils may be due to condition the materials were subjected to during drying and extraction as exposure to light and heat increases the rate of lipid oxidation. Peroxide value determines the extent to which the oil has undergone rancidity. These results might be due to the effect of high frying temperature causing destruction of some glycerides.

\section{Saponification Value}

Saponification value is an index of average molecular mass of fatty acid in the oil sample. The saponification value obtained from the oils in Table 8 shows that there is an increase in the saponification value of the oil at each time of analysis and it ranges from $190.00 \mathrm{mgKOH} / \mathrm{g}$ to $252.33 \mathrm{mg} \mathrm{KOH} / \mathrm{g}$. The values are however in the ranges of expected range of $195-205 \mathrm{mg} \mathrm{KOH} / \mathrm{g}$ oil at for edible oil as specifies by standard organization of Nigeria [17] and Nigerian interval standard [19]. The higher value of saponification values however, suggests that the mean molecular weight of fatty acid is higher or that the number of ester bonds is more. This might imply that the fat molecules do interact with each other [18]. The result generally shows an increase in the saponification value during heating and reached $252.33 \mathrm{mgKOH} / \mathrm{g}$ for Bushmango oil. High saponification value indicates that the oils are very useful in the production of liquid soap and shampoo industries [21]. Thus the values obtained from melon oil, Bushmango, olive and palm olein oil shows that they have high potential for use in the production of liquid soap and shampoo. The saponification value gives an idea about the number of ester equivalents per unit mass of the oil.

\section{Iodine Value}

Iodine value is a measure of the extent of unsaturation of fatty acid present in fat and oil. The higher the iodine value of a particular oil, the higher the degree of unsaturation of the oil. The iodine values $(\mathrm{mgI} / \mathrm{g})$ obtained during this study significantly $(\mathrm{p}<0.05)$ decreases from 110.02 to $3.01 \mathrm{mgI} / \mathrm{g}$ with highest value $(110.02 \mathrm{mgI} / \mathrm{g})$ recorded for Melon oil at fresh and $3.01 \mathrm{mgI} / \mathrm{g}$ for Bushmango at four weeks after frying. The result was an indication that the degree of unsaturation decreases with storage time. Iodine value increases the degree of unsaturation in a fat or vegetable oil. It determines the stability of oils to oxidation, and allows the overall unsaturation of the fact to be 
determined qualitatively [9]. From Table 7, the values of iodine obtained are higher compared to the ones obtained from corn oil and mustard oil which are $15.96 \mathrm{~g}$ and $8.10 \mathrm{~g}$ respectively [3]. It was also observed that the result obtained for the iodine value is highest for melon oil (110.02 I2 / 100g) and least for Bushmango oil when fresh (before frying), however, the value decreases after frying and with storage time. The high iodine value obtained for melon oil, olive oil and palm olein oil may be likened to lower oxidation storage stability, i.e., due to high iodine values obtained for these three oils may contribute to lower oxidative storage stability. On the other hand, Bushmango show a lower iodine value of $13.40 \mathrm{I} 2 / 100 \mathrm{~g}$ before it decreases progressively to $3.01 \mathrm{I} 2 / 100 \mathrm{~g}$ at 4 weeks after frying. Nevertheless, this lower iodine value for Bushmango may have contributed to its greater oxidative stability. The decrease of iodine value; 110.02 I2 / 100g -70.91 I2 / 100g of I2/100g oil, melon oil, 13.40-3.01 I2 / 100g oil for Bushmango oil, $81.20 \mathrm{I} 2 / 100 \mathrm{~g}-53.98 \mathrm{I} / 100 \mathrm{~g}$ oil for olive oil correlated well with the decrease of unsaturated fatty acids. Iodine value decrease is indicative of the increased rate of oxidation during heating and could be attributed to oxidation and polymerization reaction involving the double bonds [3].

\section{Acid Value and Free Fatty Acid Value}

Acid value indicates whether the oil is in good non-degradable state or not. The acids value of melon oil, Bushmango oil, olive oil and palm olein oil after 24 hours of frying are $6.73 \mathrm{mgKOH} / \mathrm{g}, 3.90,2.24$ and $2.24 \mathrm{mgKOH} / \mathrm{g}$ respectively had slightly value compared with that before frying, also it can be noticed that the acid value of melon oil before and after frying had the highest values $5.22 \mathrm{mgKOH} / \mathrm{g}$ (before frying) and 19.17 $\mathrm{mgKOH} / \mathrm{g}$ (after 4weeks of frying) compared with Bushmango oil, olive oil and palm olein over the same range, 3.50, 13.22, for Bushmango oil, $0.73,5.82 \mathrm{mgKOH} / \mathrm{g}$ for olive oil and 1.29, $4.49 \mathrm{mgKOH} / \mathrm{g}$ for palm olein oil. The amount of acid value (mg/KOH/g) and free fatty acid obtained in this study for local oil samples are higher than 1.7 and 0.96 reported by [13] for cashew nut oil, whereas the values obtained for the commercial samples were relatively lower than 5.993 .01 reported for ground nut oil by[14]. This indicates that the refining process in the commercial oil samples has significantly $(\mathrm{p}<0.05)$ reduced the acid value and free fatty acid contents of the commercial oil. Acid value of the oil suitable for edible purposes should not exceed $4 \mathrm{mgKOH} / \mathrm{g}$ likewise the presence of excess free fatty acid and other fatty materials in oils bring about offensive odour and taste in the oils on long storage [15]. Generally, the increase in the acid value 
of the oil samples may be attributed to the complete inhibition of enzymes activity. Thus in all cases there are corresponding low levels of free fatty acids in the oils before frying which also suggests low level of hydrolytic and lypolytic activities in the oils. However, increase in the values of free fatty acid with storage time increases the accessibility of oxygen into the oil, hence increase oxidation rate.

\section{Correlation between Free Fatty Acid and Peroxide Values of the Oil Samples}

From the different graphs of free fatty acid against peroxide values plotted for each oil sample, the correlation coefficient ranges between 0.845579 to 0.991445 with the highest value $(0.991445)$ recorded for the correlation between free fatty acid and peroxide value in melon oil. It can also be observed that this value is greater than 7.0 in each case, which indicated that there was a high degree of correlation between the free fatty acid and the peroxide value of the different oil samples. An increase in the free fatty acid led to a corresponding increase in the peroxide values of the different oil samples. This is expected because both parameters are used as a measure of lipid oxidation and an increase in one is expected to lead to a corresponding increment in the other.

\section{Conclusion}

The study has evaluated the effects of frying and storage on the physicochemical properties of the selected local and commercial oil samples using standard methods. The results of the physicochemical analysis showed that the viscosity of the oil samples increases with storage time after used for frying. The results also showed an increase generally in the peroxide, acid and free fatty acid values of the oils while iodine and saponification values decreases when analyzed at fresh and after they have been used to fry plantain and yam at 24 hours, 2 weeks and 4 weeks respectively. From the result obtained from the study, frying and storage affects the quality of cooking oils. It is therefore recommended that the consumption of fried vegetable oils beyond a period of two (2) weeks could be dangerous health-wise and beyond this period, it should be avoided completely. It is recommended that the manufacturers of edible vegetables oils include in the packaging of their products the maximum time particular oil can be used to fry before it is discarded and also the time of storage after use. It is also recommended that further research works such as the Thiobarbituric Acid test could be done to measure the susceptibility and the progress of peroxidation in local and commercial oil samples. 


\section{References}

[1] K. P. Ghosh, D. Chatterjee and P. Bhattacharjee, Alternative methods of frying and antioxidant stability in soybean oil, Advance Journal of Food Science and Technology 4 (2012), 26-33.

[2] Diana Moigradean, Mariana-Atena Poiana and Ioan Gogoasa, Quality characteristics and oxidative stability of coconut oil during storage, Clean Products and Processes 18 (2012), 272-276.

[3] Erum Zahir, Rehana Saeed, Mehwish Abdul Hameed and Anjum Yousuf, Study of physicochemical properties of edible oil and evaluation of frying oil quality by Fourier Transform-Infrared (FT-IR) Spectroscopy, Arabian Journal of Chemistry 10 (2017), S3870-S3876. https://doi.org/10.1016/j.arabjc.2014.05.025

[4] E. Choe and D. B. Min, Chemistry of deep-fat frying oils, Journal of Food Science 72 (2007), R77-R86. https://doi.org/10.1111/j.1750-3841.2007.00352.x

[5] E. Mensah and G. Y. Obeng, Assessment and projection of waste vegetable oils from hotels for biodiesel feedstock and $\mathrm{CO} 2$ savings in Ghana, International Journal of Engineering Research and Science \& Technology 2(4) (2013), 1-12.

[6] J. Good, Healthiest Cooking Oil Chart with Smoke Points, Baseline of Health Foundation, 2012. https://www.jonbarron.org/article/healthiest-cooking-oil-chart-smokepoints

[7] Y. B. Che Man and I. Jaswir, Effect of rosemary and sage extracts on frying performance of refined, bleached and deodorized (RBD) palm olein during deep fat frying, Food Chemistry 69 (2000), 301-307. https://doi.org/10.1016/S0308-8146(99)00270-8

[8] M. Rani and G. S. Chauhan, Effect of intermittent frying and frying medium on the quality of potato chips, Food Chemistry 54 (1995), 365-368. https://doi.org/10.1016/0308-8146(95)00019-F

[9] AOAC, Official Method of Analysis, 15th ed., Association of Official Analytical Chemists, Washington DC, USA, 1990, pp. 84-89.

[10] G. Boskou, F. N. Salta, A. Chiou, E. Troullidou and N. K. Andrikopoulos, Content of trans,trans-2,4-decadienal in deep-fried and pan-fried potatoes, European Journal of Lipid Science and Technology 108 (2006), 109-115.

https://doi.org/10.1002/ejlt.200500236

[11] R. L. McCormick, T. L. Alleman, M. Ratcliffe, L. Moens and R. Lawrence, Survey of the quality and stability of biodiesel and biodiesel blends in the united states in 2004, National Renewable Energy Lab. (NREL), Golden, CO (United States), Technical Report No. NREL/TP-540-38836, 2005. https://doi.org/10.2172/8599092005 
[12] G. W. Ayoade, I. A. Amoo and V. O. E. Akpambang, Physicochemical and fatty acid composition of crude and refined oils of African canarium, International Journal of Science and Technology 4 (2015), 230-234.

[13] I. A. Amoo, Proximate composition, minerals and physicochemical properties of cashew nut and oil, Journal of Food Science Technology 42 (2005). 445-446.

[14] V. N. Atasie, T. F. Akinhanmi and C. C. Ojiodu, Proximate analysis and physicochemical properties of groundnut (Arachis hypogaea L.), Pakistan Journal of Nutrition 8 (2009), 194-197. https://doi.org/10.3923/pjn.2009.194.197

[15] H. Egan, R. S. Kirk and R. Sawyer, Pearson's Chemical Analysis of Food, 8th ed., London: Churchill Livingstone, 1981.

[16] A. Romeo, C. Cuesta and F. J. Sanchez-Muniz, Cyclic fatty acid monomers in high oleic acid sunflower oil and extra virgin olive oil used in repeated frying of fresh potatoes, $J$. Am. Oil Chem. Soc. 80 (2003), 437-442.

[17] SON, Standard Organization of Nigeria, Standards for Edible Refined Palm Oil and Its Processed Form, 2000, pp. 2-5.

[18] K. J. Dennison, J. J. Topping and R. L. Cariet, General Organic and Biochemistry, 4th ed., New York: McGraw Hill Companies, 2004, pp. 432-433.

[19] NIS, Nigerian Industrial Standards, Standard for Edible Vegetable Oil, 1992, pp. 5-12.

[20] CODEX 2005, Standard for Named Vegetable Oils, Codex Alimentarius International Food Standards, 2005, pp. 45-56.

[21] H. Akbarirad, A. Gohari Ardabili, S. M. Kazemeini and A. Mousavi Khaneghah, An overview on some of important sources of natural antioxidants, International Food Research Journal 23 (2016), 928-933. 